\title{
The Development of Critical Thinking Skills and Collaborative Skill Profiles Aided by Multimedia-based Integrated Instruction on Light Refraction Material
}

\author{
Parsaoran Siahaan, Yusa Chavez Setiawan, Nuzulira Janeusse Fratiwi, Achmad Samsudin, \\ Endi Suhendi*
}

Department of Physics Education, Universitas Pendidikan Indonesia, Indonesia

Received March 30, 2020; Revised April 27, 2020; Accepted May 27, 2020

Copyright $@ 2020$ by authors, all rights reserved. Authors agree that this article remains permanently open access under the terms of the Creative Commons Attribution License 4.0 International License

\begin{abstract}
Along with the rapid development of technology in the $21^{\text {st }}$ century, students are not only required to understand the cognitive aspects, but also skills such as critical thinking and collaboration that are important to be trained so that they have an ability to adapt quickly. Critical thinking and collaborative skills can be trained on students with learning that is integrated with computer multimedia. This study was aimed at identifying the improvement of critical thinking skills and the profile of students' collaborative skills using multimedia-based integrated instruction $\left(\mathrm{MBI}_{2}\right)$. The research method used was Pre-Experimental with One Group Pretest Posttest Design. The participants of this study involved 33 students (consisting of 13 boys and 20 girls) in grade VIII in one state junior high school in Bandung. The results showed that the increase in students' critical thinking skills was in the medium category with an $\mathrm{N}$-gain value $\langle\mathrm{g}\rangle=0.42$ and the collaborative skills profile of the students was in the good category. Based on the results of this study, it can be concluded that the use of $\mathrm{MBI}_{2}$ learning can develop critical thinking and collaborative skills of secondary school students on light refraction material.
\end{abstract}

Keywords Critical Thinking Skills, Collaborative Skills, Multimedia-based Integrated Instruction $\left(\mathrm{MBI}_{2}\right)$, Light Refraction

\section{Introduction}

Learning process is a pivotal part of human life. Humans always learn either as a need to adapt or to survive, to satisfy a sense of curiosity in solving complex problems in the society at large. Learning is also a process of knowledge transfer which generally we know as the interaction of teachers and students. The shift of the learning paradigm from teacher center towards student center learning is expected to improve the quality of education today. This paradigm emphasizes how students can learn well with the teacher as a facilitator in learning. The government formulates that the $21^{\text {st }}$ century learning paradigm directs students to find out information from various sources, to formulate problems, to think analytically and to emphasize the importance of cooperation and collaboration in solving problems [1]. The problem is that when it comes to learning in class students always depend on the knowledge conveyed by the teacher so that the teacher becomes the center of learning (teacher center learning), students are more dominant to listen and record material written on the board, and students often get homework assignments to do individually. Learning in the 2013 curriculum is carried out using a scientific approach. The scientific learning approach can make students more productive, creative, innovative, and affective through strengthening the integrated realm of attitudes, skills and knowledge [2]. The learning process based on the 2013 curriculum requires students to be more active and motivated in learning activities. In this curriculum students are expected to be more critical and independent in the learning process. The affective aspect that appears at each meeting varies according to the demands on the teacher's book. Curiosity, independence, and confidence are the affective score that are expected to emerge [3].

In the $21^{\text {st }}$ century the science and knowledge are advancing so that each country has a strategy that must be developed to deal with it. The $21^{\text {st }}$ century is also marked by the amount (1) of information available anywhere and 
can be accessed at any time; (2) faster computing; (3) automation that replaces routine jobs; and (4) communication that can be done from anywhere and anytime. In this information age, all types of work are required to have more skills. The type of career that requires higher knowledge and science as well as expert mindset and complex communication skills is more promising than repetitive work $[1,4]$.

The $21^{\text {st }}$ century skills are skills required by the world community in facing the $21^{\text {st }}$ century. These skills are very important to be mastered by everyone and are embedded in the Indonesian curriculum to be able to compete with outsiders and make Indonesia a more quality and advanced country. True education is a student center process. Students are expected to be able to hone their hard skills and soft skills by being trained and enhanced their abilities and skills to be able to overcome various global challenges. The preferred skills emerge according to the Partnership for 21st Century Skills, which are four skill dimensions consisting of Learning and Innovation Skills, Information, Media and Technology Skills, and Life and Career Skills [5].

There is one dimension of the 21st century, namely skill dimension, which is divided into four main pillars in $21^{\text {st }}$ century learning, namely Critical Thinking, Communication, Creativity, and Collaboration. This is in line with Trilling \& Fadel [6] that divides the ability of the $21^{\text {st }}$ century into three namely: critical thinking and Problem solving, applying skills such as critical thinking, problem solving, and creativity for content knowledge. Improving motivation and learning outcomes; Communication and Collaboration, Education always pays attention to the basics of good communication, correct speech, fluent reading, and clear writing. Collaboration is needed to improve the ability to work together; Creativity and Innovation, Innovating in new services, better processes and improves products for the global economy. Creativity is needed in adjusting to work that began to be flexible in the $21^{\text {st }}$ century. These four skills are better known as 4Cs Super Skills. 4Cs Super Skills are also a key to the overall vision of $21^{\text {st }}$ century learning. The 4Cs Super Skills skill is the most appropriate skill to improve the quality of students who have entered the $21^{\text {st }}$ century in order to be able to achieve success both in continuing their studies to university, career, or society [5,7].

In this era, students are familiar with technology even from an early age. Ironically, such familiarity and comfort are inversely proportional to all current digital challenges for educators who struggle to keep up with the changing technological context, where students no longer process information gradually, but instantaneously [8]. Learning activities with the help of computers can be an alternative solution to the aforementioned problems. By presenting technology as a bridge in teaching and learning activities, it is expected to be able to answer digital challenges that require skills that need to be trained on students. Multimedia is one way to convey learning with the help of computers. Specifically, multimedia is used to facilitate learning. Multimedia learning can be used to channel messages (communicate), stimulate students' thoughts, feelings, concerns and motivations, so that they can encourage the learning process [9]. In learning, multimedia with the help of computers uses one-way instructional media commonly called Computer Assisted Instruction (CAI). According to Wondal, CAI applies graphic and animation programs to create instructional and interactive media that can illustrate concepts through animation, sound and demonstration [10]. CAM (Computer Assisted Multimedia) is able to transfer information easily and quickly. In general, the computer media used by teachers in schools are only limited to the Power Point program to increase students' understanding of a concept [11].

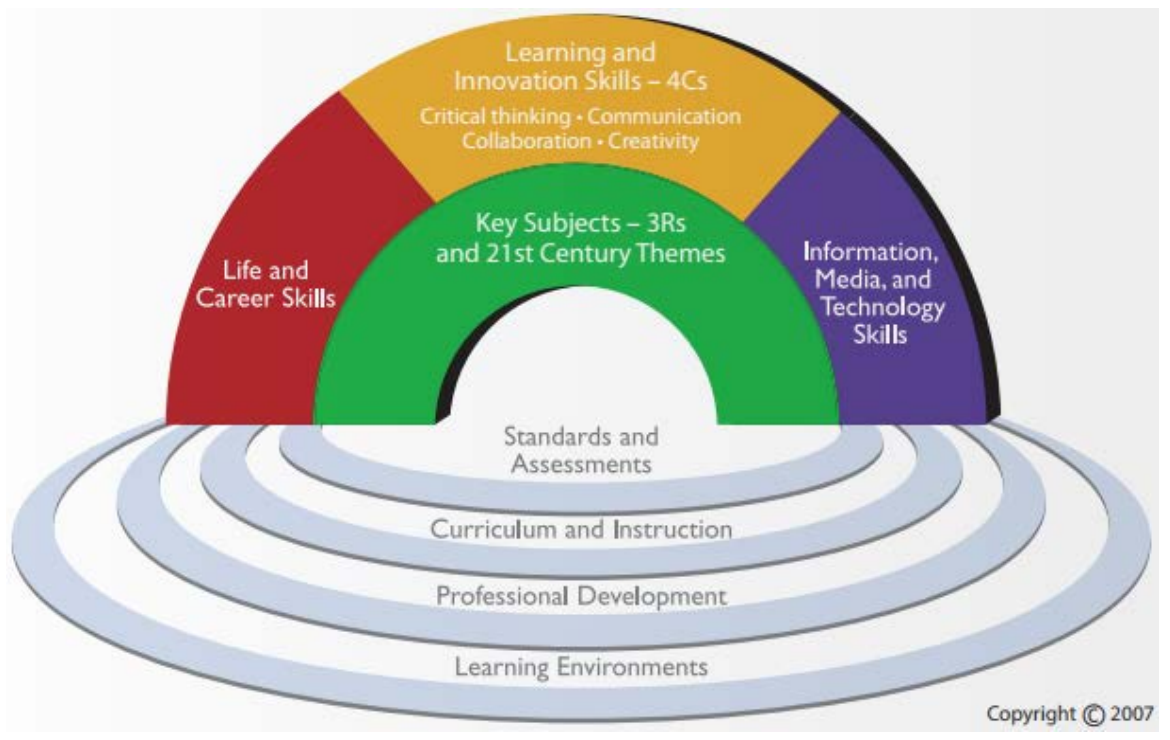

Figure 1. Four Dimensions of $21^{\text {st }}$ century Skills 
Multimedia-based Integrated Instruction $\left(\mathrm{MBI}_{2}\right)$ is multimedia that is equipped with interactive content such as animations and simulations so that learning can be improved in learning on material that is difficult to observe, or which cannot be done in real experiments. Hermawan [12] stated that $\mathrm{MBI}_{2}$ was a further development of CAI to convey information and instructions directly in directing interactive simulations of learning. The $\mathrm{MBI}_{2}$ made includes all components of the lesson plan, namely (1) Curriculum. (2) Mind Mapping, (3) Materials, (4) Worksheet, (5) E-books, and (6) Evaluations in the form of questions.

Based on the consideration of the results of the preliminary study, the researcher proposed the Multimedia Based Integrated Instruction $\left(\mathrm{MBI}_{2}\right)$ learning media as one solution to answer the problems that have been previously described. $\mathrm{MBI}_{2}$ is an integrated multimedia which contains learning multimedia, learning tools, teaching materials (e-books), assessment based on multimedia both in the form of computer simulations and animations in learning media, assessments as well as videos and e-books as teaching material so that learning science (Physics) using $\mathrm{MBI}_{2}$ will be more efficient and time saving, also give new experiences to students.

Several previous studies have linked the application of $\mathrm{MBI}_{2}$ to determine the profile or improvement of skills included in $21^{\text {st }}$ century skills, such as Hermawan's research that has examined the use of $\mathrm{MBI}_{2}$ on the profile of the ability to collaborate on light reflecting material [12]; Bhakti examined the development of multiple choice tests to measure students' generic science skills on solar system concepts [13]; Samsudin's research on the development of scientific creativity skills tests on material earth structures [14]; the development of problem solving skills tests on the material of Vibrations, Waves, and Sounds studied in Hidayat's research [15]; analysis of problem-solving ability on heat transfer material conducted by Yulianawati [16]; Nurasiah conducted research to measure the increase in critical thinking skills in optical instrument materials [17]; and the improvement of science process skills in regular straight motion material studied by Siahaan [18].

This study was aimed at finding out ways to improve critical thinking skills and collaborative profiles in learning science / physics, especially on light refraction material. Learning with computer media is expected to maximize the absorption of information by students, which are presented in the form of instructional media, teaching materials, and assessment with the help of computers. So, it is expected that students' critical thinking and collaborative skills can grow and even enhance. In this study, researchers developed media using $\mathrm{MBI}_{2}$. The use of $\mathrm{MBI}_{2}$ in science learning is used to develop the two $21^{\text {st }}$ century skills, namely critical thinking skills and student collaboration with the focus of light refraction material. The material implemented into
$\mathrm{MBI}_{2}$ was the light refraction material that is available in the seventh-grade junior high school curriculum in semester 2 .

\section{Materials and Methods}

\subsection{Participant}

A total of 33 students of grade VIII from one state Junior High School in Bandung participated as a sample in this study. All participants came from the same class, consisting of 13 boys and 20 girls. The average age of the sample was in the range of 13-14 years old. During the learning activities took place, students were divided into groups consisting of 4-7 students who were randomly determined.

The researcher employed a purposive sampling technique to determine the sample from the study on the grounds that the researcher tried to make the sample from this study homogeneous and could represent the population of junior high school students in the city of Bandung. Another reason for selecting the sample was also because the facilities of the participant class that have been adequately included the availability of laptop devices that have been provided by the school were the main means of learning using $\mathrm{MBI}_{2}$ which was the focus of this study. The class selection was also due to other classes that had or were studying light refraction material, and the science teacher of the class has not taught light refraction material.

\subsection{Research Design}

Before conducting research, researchers should consider the methods and designs that will be used in the study. If we review, the outline of this study was aimed at observing changes in predetermined variables that were affected by a treatment. After reviewing the literature as reference material, the researcher determined the quantitative method namely pre-experimental method as the method of the study. The pre-experimental research method is a research method used to determine the effect of a variable on other variables without the control variables and the sample is not randomly selected. The selection of research methods also aimed at limiting the scope of the research to focus on the variable of the students' ability to collaborate and the ability to think critically. The researcher also took the sample purposely without a control class with the consideration that it was impossible for two classes to have the exact same conditions $[19,20]$. There were two different research designs to find out the increase in critical thinking skills and collaborative skills profiles, namely one group pretest-posttest design and one-group posttest-only design. 


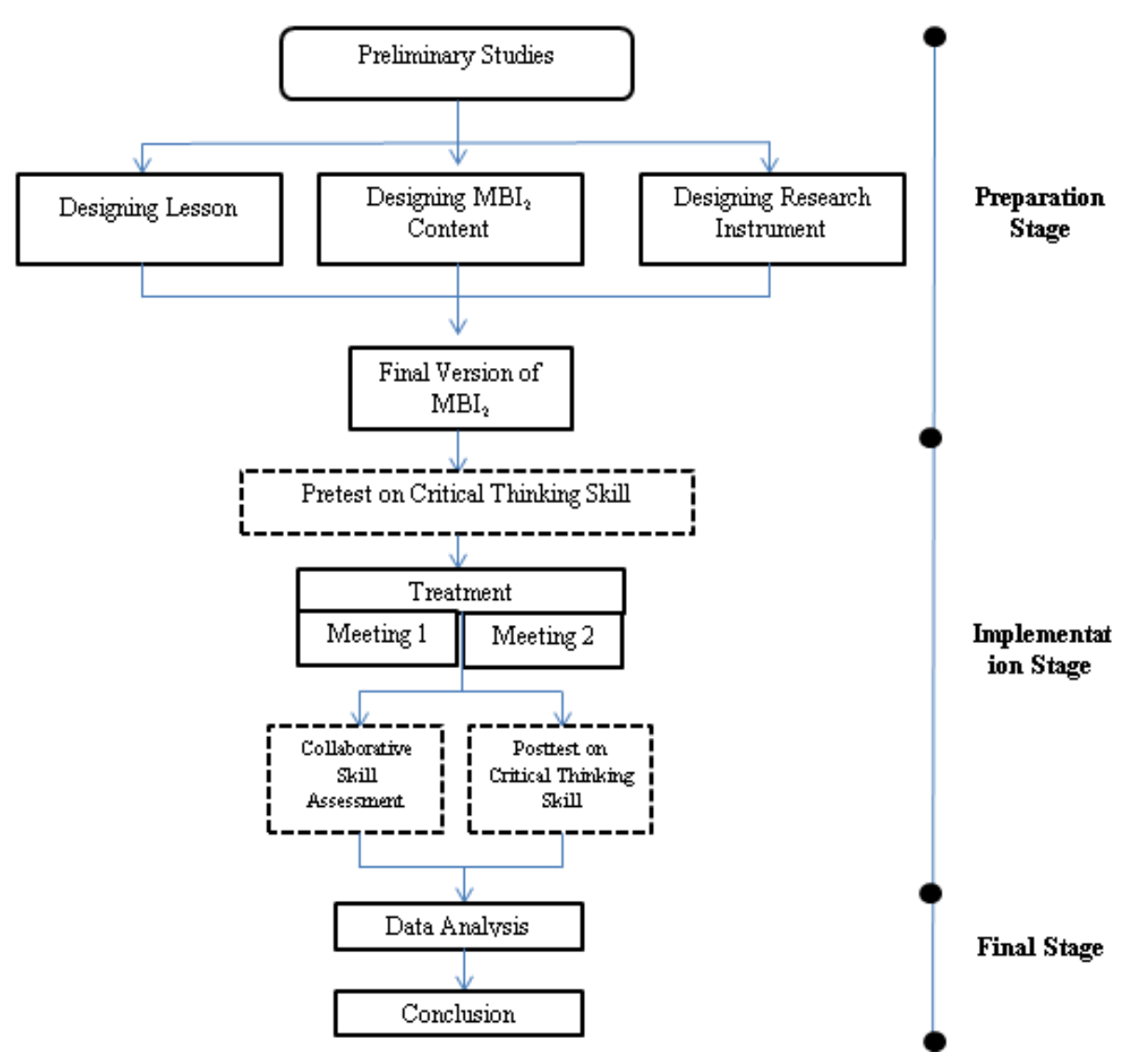

Figure 2. The Research Flowchart

The research design used to measure critical thinking skills was the One Group Pretest-Posttest design. In this approach, all participants were initially determined as an experimental group. Then, the group was observed at two different times. One observation in the form of a pretest was recorded before the intervention (independent variable). Then after the intervention, observation or the second data retrieval was done in the form of posttest. The change from pretest to posttest was an interesting result, which was considered the result of treatment $[19,20]$. Whereas the research design to determine the profile of students' collaborative skills in this study was a one-group posttest-only design, also called a one-shot case study. In this design, all participants were assigned non-randomly as an experimental group. Then, all participants in this group were presented with several types of treatments, such as curriculum or new learning models. After that, the final result was measured as the only posttest.

This research lasted for 2 meetings, with the duration of each meeting for $3 \times 40$ minutes. In outline, this research is divided into three phases which consist of preparation, implementation, and final stages. A description of the flow of this research is presented in Figure 2.

\subsection{Research Instrument}

The dependent variables that were measured in this study were critical thinking skills and student collaboration skills. The material implemented in learning using $\mathrm{MBI}_{2}$ was light refraction. Critical thinking skills were skills possessed by a person in analyzing an event or problem and being able to choose the actions that must be taken to solve a problem which is meant in this research consisting of scientific and intellectual disciplinary processes, which were active and skillful to conceptualize, implement, analyze, synthesize, and evaluate information that has been collected from observations, experiences, reflections, reasons, as instructions for action [21]. There are five aspects of skills taken from the rubric of critical thinking skills proposed by Ennis [22] that are used to measure improvement in students' critical thinking skills, namely clarifying, building the basis for decision making, concluding, making further explanations, and making guesses \& integrating them.

According to Fathan et al. [9] thinking is defined as a mental process that can produce knowledge. In general, the activity of thinking is divided into two, namely low order thinking and high order thinking. High order thinking is a thinking skill that not only requires the ability to remember, but also requires other higher skills [9]. According to Ennis, critical thinking is a skill to convey reasons and reflect thinking focused on decision making on what is believed or done [22]. The aspects of critical thinking ability proposed by Ennis are presented in detail in Table 1. 
Table 1. Aspects of Critical Thinking Skills

\begin{tabular}{|c|c|c|}
\hline Aspects of critical thinking skills & Sub aspect of critical thinking & $\begin{array}{c}\text { Description indicators Sub aspect of critical } \\
\text { thinking skills }\end{array}$ \\
\hline clarifying & Identifying a focus question & Identifying criteria of possible answer \\
\hline Establishing the basis for a decision & Considering the credibility of the source & Skills of giving reasons \\
\hline Concluding & $\begin{array}{c}\text { Inducing and considering induction } \\
\text { results }\end{array}$ & Defining \\
\hline Making further explanation & Defining the content of a term \\
\hline Making assumptions and Integrating & Considering decisions based on reason & $\begin{array}{c}\text { Choosing criteria as a possible solution to the } \\
\text { problem }\end{array}$ \\
\hline
\end{tabular}

Critical thinking skills were measured using critical thinking skills test instruments in the form of multiple-choice questions. Data enhancement of critical thinking skills were analyzed based on the value of $\mathrm{N}$-gain score pretest-posttest. The research instrument used to test students' critical thinking skills such as critical thinking skills test on light refraction material consists of 10 multiple-choice items. Figure 3 presents an example of the grating of test critical thinking skills.

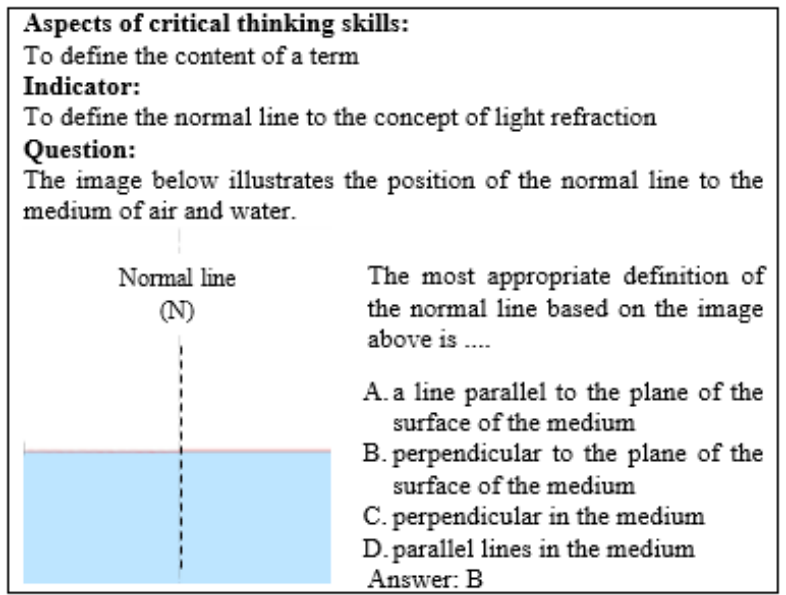

Figure 3. Example of Grid Question about Critical Thinking Ability Test

Collaboration skills are also an important skill for every person who lives in the 21st century. According to Niemi et al. collaborating is a social mediator that allows or requires students to collaborate [23]. In order for collaborative skills to be possessed by students, educators should take steps such as encouraging students to exchange ideas, opinions, knowledge, help one another, work together, actively seek help, justify and explain ideas, and provide explanations by being described in full [24]. In addition, according to Trilling \& Fadel [6] so students can be said to have collaborative skills, students must be able to demonstrate the following skills: demonstrate effective work skills and respect team diversity; demonstrate flexibility and willingness to accept other people's opinions in achieving common goals; and assume joint responsibility for collaborative work and appreciate the contribution of each team member.
The collaborative skills referred to in this study are social skills that enable or require students to work together with others. The indicators of collaborative skills assessed are divided into four indicators, (1) collaboration skills and attitudes of respect for group members; (2) the skills of participating and contributing to groups; (3) time management skills in working on tasks; (4) and skills to be responsible for the results of joint work. Students' collaborative skills are assessed by observers in practicum activities in groups. Students are assessed using instruments in the form of collaborative skills rubrics. The Collaborative Skills Rubric is an adaptation of the Partnership of 21, "21st Century Skills Rubric" and International Reading Association/NCTE Read Write Think "Collaborative Work Skills Rubric" [25,26]. The collaborative skills scores are categorized so that a student's collaborative skills profile is obtained. Based on the collaborative skills students must master as described above, these skills are classified into aspects of collaborative skills that will be trained and measured.

To measure the profile of students' collaborative skills, the instrument used was a collaborative skills observation sheet consisting of 4 indicators, cooperative skills and respect for group members; skills in participating and contributing to groups; time management skills in working on tasks; and skills to be responsible for the results of joint work. Each indicator was equipped with a description of the achievement criteria with a score of 1 to 4 , a score of 1 indicates that the student has not achieved the expected competency, a score of 2 indicates that the student is close to the expected competency, a score of 3 indicates that the student has achieved the expected competency, and a score of 4 indicates that the student exceeds the competency expected on the indicator. In this study, researchers included observers with one observer in each group to assess the collaborative skills of each student in one group.

\subsection{Data Analysis}

In this study, researchers would analyze some data relating to the improvement of critical thinking skills and collaborative skills profiles, therefore data collection techniques and data processing techniques were needed to be analyzed and answer the research problem formulation. 
The data obtained consisted of two types, namely critical thinking skills data and collaborative skills obtained from test and observation results. Quantitative data obtained in this study came from the results of the assessment of critical thinking skills using the critical thinking skills test instrument which was assessed using the rubric / key of the test answers. Data on this test were taken twice, namely the pretest and posttest. Data that have been processed using $\mathrm{N}$-gain were interpreted into several categories, and then were analyzed as a whole in each indicator of critical thinking skills in detail with descriptive analysis.

$\mathrm{N}$-gain provides a general description of the improvement in student learning outcomes before and after treatment is given by classifying it into several categories of N-gain values adapted from Hake [27]. Data that has been calculated using $\mathrm{N}$-gain and has been interpreted into several categories, then analyzed both overall and each indicator of critical thinking skills.

For the profile of students' collaborative skills, this instrument is used during the process of learning science refracting materials using $\mathrm{MBI}_{2}$. Each indicator was given a score based on the assessment criteria in number of 1,2 , 3 , and 4 with the lowest criteria scale was given a score of 1 and the highest criterion was 4. Assessment in each aspect was carried out according to the guidelines for collaborative skills rubric. Furthermore, the scores were added from each indicator into the total score of students' collaborative skills. The sum of the scores obtained by students interpreted as a profile of students' collaborative skills. Collaboration skills categorization refers to the scoring rules for the assessment of psychomotor domains that have been adapted from Arifin [28]. To find out the interpretation of collaborative skill scores on each indicator, the 21st Century skill score interpretation guideline was used which was adapted from 21st Century's Skills Rubric [25].

\section{Findings and Discussion}

Critical thinking skills of students were assessed based on the results of answers to students' critical thinking skills tests consisting of ten multiple choice questions. The pretest was held before students received treatment in the form of the use of Multimedia Based Integrated Instruction $\left(\mathrm{MBI}_{2}\right)$ in learning light refraction material during two meetings. After the refraction of light material having been delivered in two meetings, students implemented posttest critical thinking skills with the same problem instrument. Of the total 35 students in the class, the number of students who took the critical thinking skills pretest was 35 people with information from 15 male students and 20 female students, while the number of students who took the posttest was 33 students with 13 male and 20 female students. Therefore, the total data of students' critical thinking skills scores that were analyzed in this study was 33 data, that was the data of all students who took part in the entire $\mathrm{MBI}_{2}$ learning activity on refracting material, following the pretest and posttest Critical Thinking Skills Test. Data on average N-gain values of students' critical thinking skills were presented in Table 2.

Based on the Table 2, the increase of students' critical thinking skills obtained an N-gain value of 0.42 . It can be stated that after giving treatment in research in the form of the use of Multimedia Based Integrated Instruction $\left(\mathrm{MBI}_{2}\right)$ on the refraction of light material, students' critical thinking skills increased in the medium category based on the categorization of N-gain values proposed by Hake [27]. The findings obtained were in line with the results of research conducted by previous studies [9,29,30,31] which stated that learning with the use of computer multimedia could improve students' critical thinking skills. As well as the use of computer multimedia aids used in this study, some of the above studies used Multimedia Based Integrated Instruction $\left(\mathrm{MBI}_{2}\right)$ which showed the same results in increasing students' critical thinking skills.

Moreover, there are five aspects of critical thinking skills that are measured in the study consisting of clarifying, establishing basis for a decision, concluding, making further explanations and making assumptions and integration. The mean value of the $\mathrm{N}$-gain in each aspect of critical thinking ability was shown at Table 3 .

Table 2. The Mean Value of the N-gain of Critical Thinking Skills

\begin{tabular}{|c|c|c|c|c|}
\hline The average score of pre-test & The average score of post-test & Ideal score & N-gain & Category \\
\hline 33.03 & 61.21 & 100 & 0.42 & moderate \\
\hline
\end{tabular}

Table 3. The Mean Value of the N-gain Every Aspect of Critical Thinking Ability

\begin{tabular}{|c|c|c|c|c|c|}
\hline Aspects CBC & The average score pre-test & The average score post-test & Ideal score & N-gain & Category \\
\hline Clarifying & 21.21 & 43.94 & 100 & 0.29 & low \\
\hline $\begin{array}{c}\text { Establishing the basis for a } \\
\text { decision }\end{array}$ & 33.33 & 57.58 & 100 & 0.36 & moderate \\
\hline Concluding & 22.73 & 57.58 & 100 & 0.45 & moderate \\
\hline Making further explanation & 46.97 & 77.27 & 100 & 0.57 & moderate \\
\hline $\begin{array}{c}\text { Making assumptions and } \\
\text { integrating }\end{array}$ & 40.91 & 69.70 & 100 & 0.49 & moderate \\
\hline
\end{tabular}


The indicators of critical thinking skills examined in this study were adapted from the five aspects of critical thinking ability proposed by Ennis [22]. These aspects consist of 1) clarifying, 2) building or establishing a basis for decision making, 3) concluding, 4) making further explanations, and 5) making assumptions \& integration. These five aspects were implemented and raised in learning using $\mathrm{MBI}_{2}$. Based on Table 3 it was found that these four aspects of critical thinking skills had increased in the medium category, and one aspect of critical thinking skills had increased in the low category. This improvement in each aspect of critical thinking skills has various $\mathrm{N}$-gain values. The aspect of critical thinking skills that experienced the highest increase was the aspect of making further explanation with an $\mathrm{N}$-gain value of 0.57 . The lowest increase was in the clarifying aspect with an $\mathrm{N}$-gain value of 0.29 . The $\mathrm{N}$-gain value which was smaller than 0.30 made clarifying aspect be in the low category. The comparison graph of the $\mathrm{N}$-gain value of each aspect of students' critical thinking skills was presented in Figure 4.

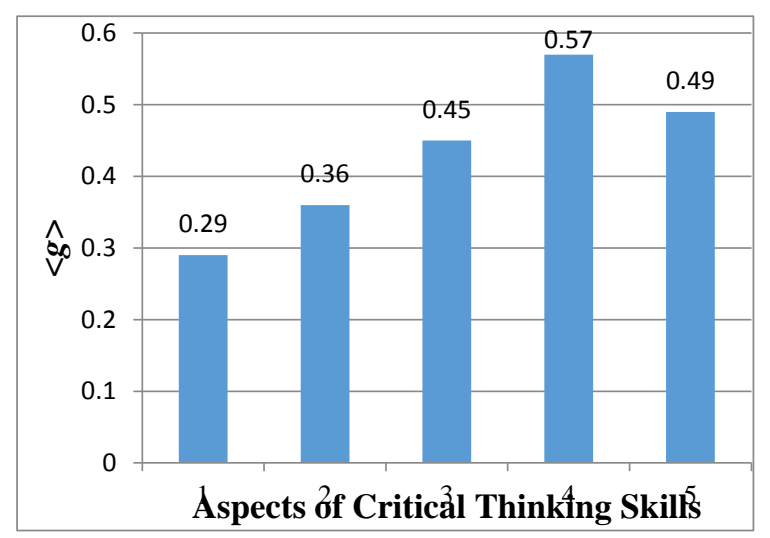

Information:

Aspect 1: Clarifying

Aspect 2: Establishing the basis for a decision

Aspect 3: Concluding

Aspect 4: Making further explanation

Aspect 5: Making assumptions and integration

Figure 4. Comparative Value of N-gain in Every Aspect of Critical
Thinking Skills

Based on Figure 4, the highest aspects of critical thinking skills of students were found in aspect number 4 , which was making further explanation. The clarifying aspect was the aspect with the lowest value compared to other aspects. These findings were in line with the results of previous studies [32] which examined Ennis's critical thinking skills based on five aspects which were the same as aspects of critical thinking skills in this study. This research also showed the results that aspects of clarifying critical thinking skills have the lowest value compared to other aspects of critical thinking skills; while the aspect that has the highest $\mathrm{N}$-gain value is the aspect of making further explanation. The graphs of the results of previous studies that supported the results of this study were presented in Figure 5.

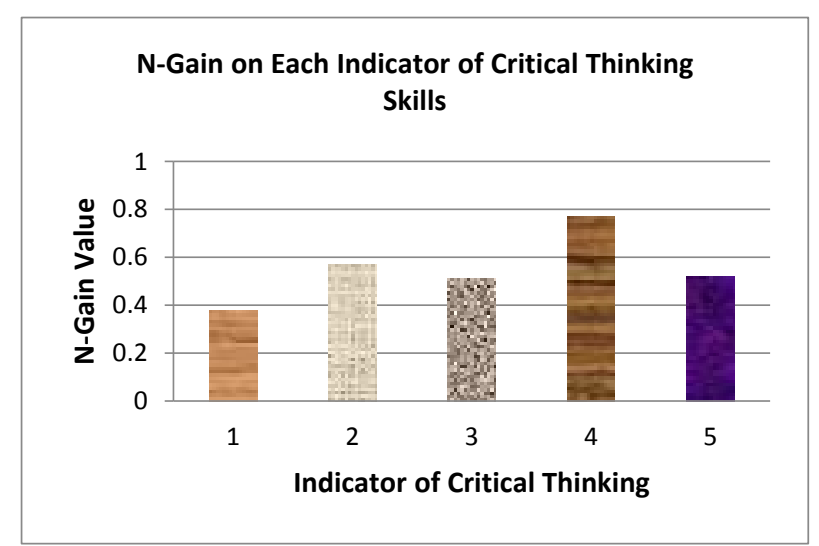

Figure 5. Comparison of N-gain Values of Each Indicator of Student's Critical Thinking Skills on Vibrations, Waves and Sound Material

Based on the theory put forward by Ennis [22] at clarifying aspects of thinking skills (Basic Clarification), students were required to define a case as well as to review the definition of what was appropriate from an event or thing that happens [32]. There were two multiple-choice items made to test the aspect of clarifying. The example of test question to measure aspects of critical thinking skills were presented in Figure 6. 


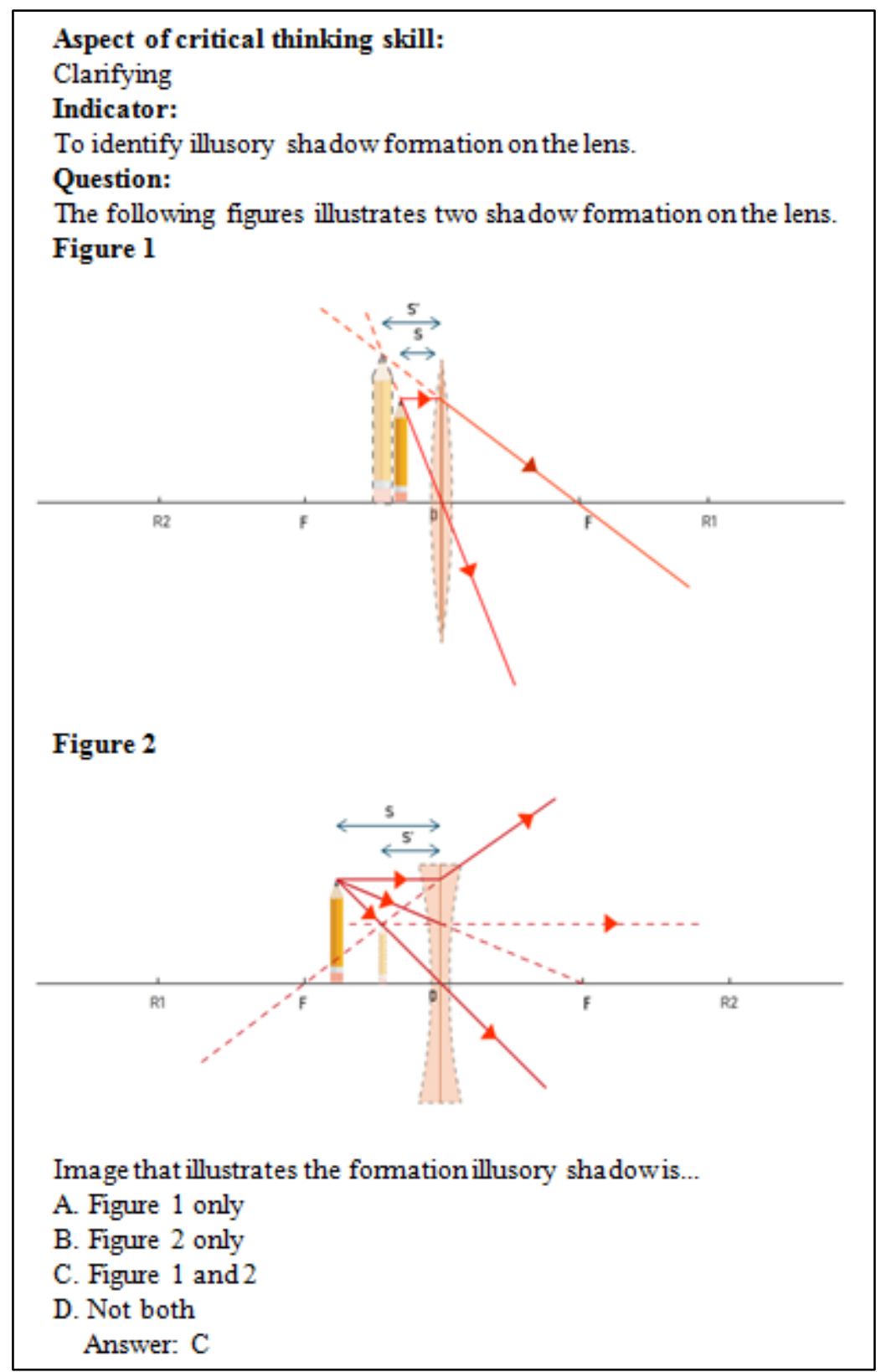

Figure 6. The Example of Test Question to Measure Aspects of Critical Thinking Skills

In learning activities using $\mathrm{MBI}_{2}$, critical thinking skills on clarifying were trained by displaying physical phenomena that were related to the concept. Then, the teacher and students discussed with each other to obtain the definition of the concept while the example of the multimedia display provided was presented in Figure 7. 

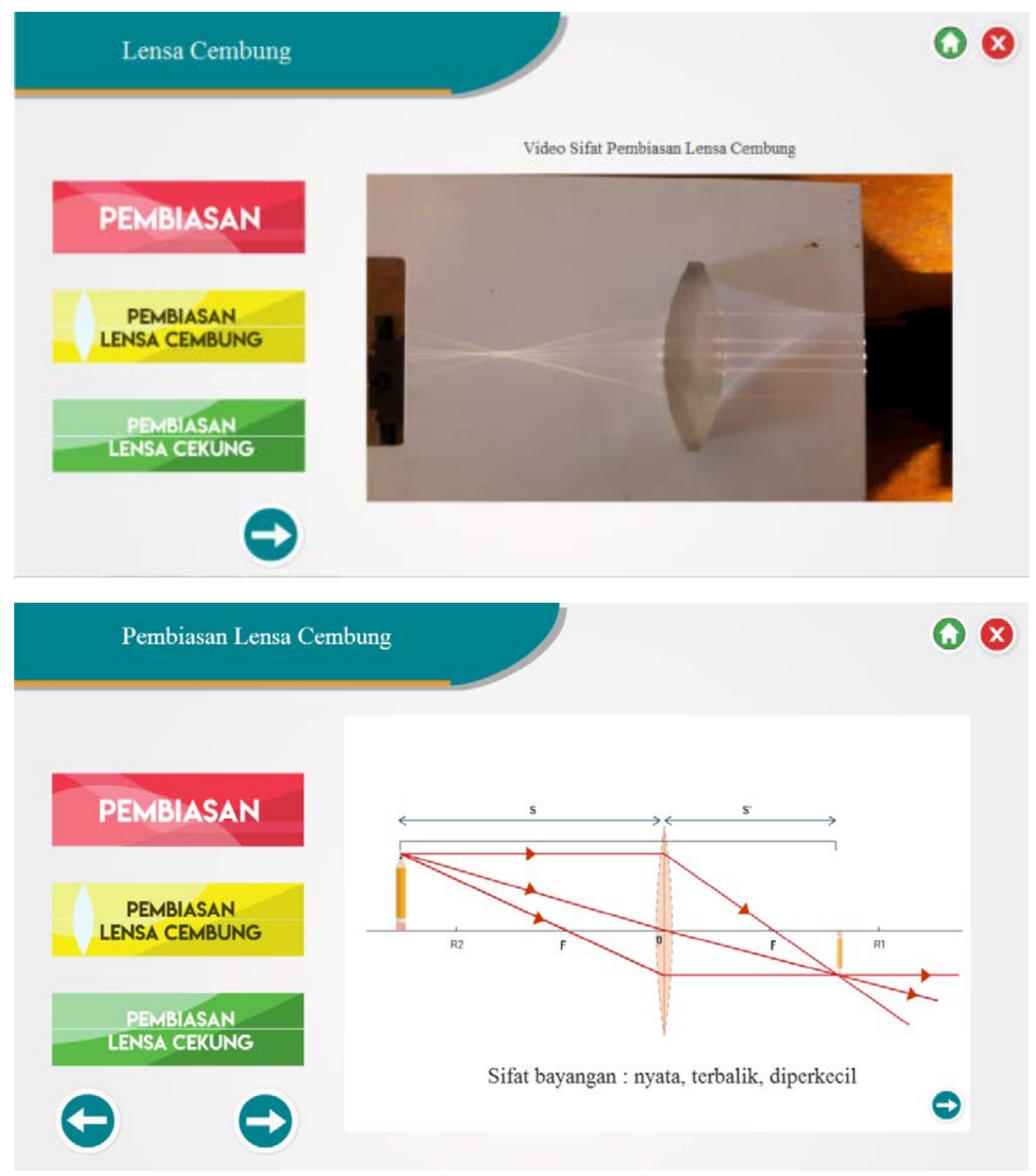

Figure 7. Example of $\mathrm{MBI}_{2}$ Display. (a) Video of line formation of light as they pass through a convex lens. (b) Simulation of the formation of an object's shadow based on the path of light passing through a convex lens

From the two $\mathrm{MBI}_{2}$ displays, students were trained to identify patterns of formation of light trajectories that passed through convex lenses. Students observed how the light passing through the lens was refracted so that it intersected at a certain point. The video display at the first Figure 7 aimed to guide students to identify the nature of the convex lens that was collecting light passing through it. In the second Figure 7, a simulation displays of the shaping of objects based on the path diagram of light. Light from objects passing through the convex lens produced intersections of light paths where the object's shadow was formed. Students were trained to be able to identify the nature of the formation of shadows based on the comparison of the shape of the object's original shadow shape.

The aspect of giving further explanation became the aspect which had the highest $\mathrm{N}$-gain value compared to other aspects. It was inversely related to clarifying aspects. There were two items of the critical thinking skills test instrument in the form of multiple choice which were used to test aspects of giving further explanation. Both of these items tested students to explain the further meaning of a concept that was raised. Figure 8 presented one example of the items used to test the critical thinking skills aspects of providing further explanation. 


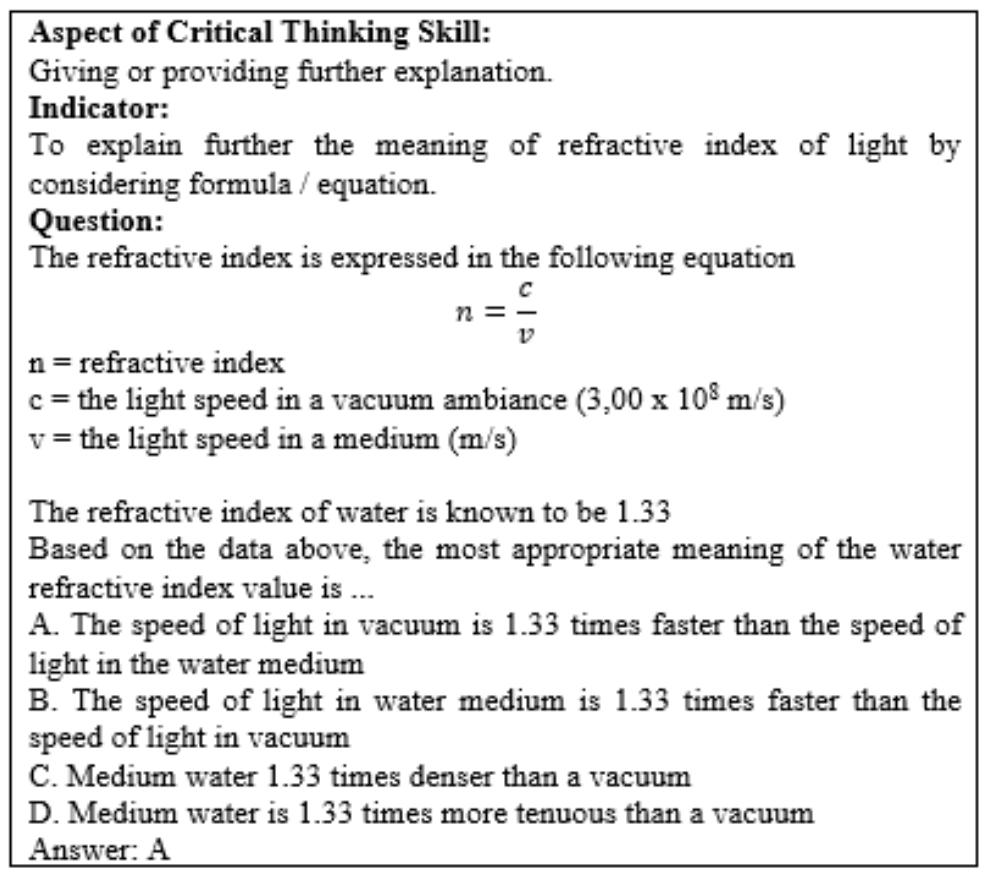

Figure 8. Examples of Critical Thinking Ability Test Question on Aspects of Providing Further Explanation

For this aspect, students were expected to be able to define the meaning of terms that emerge from a concept, such as explaining the definition or further meaning of an equation. In problem-based learning activities (PBL) students were trained to explain various kinds of phenomena that appear that were displayed in simulations, videos, or pictures in $\mathrm{MBI}_{2}$. The results of this study were in line with research conducted which stated that problem-based learning could improve students' critical thinking skills [33].

$\mathrm{MBI}_{2}$ was not only used as a learning resource, but it was also used in practicum activities carried out at each meeting as a learning support media. Every practicum activity, students were assigned to fill student worksheet in groups. This worksheet was expected to train students directly to get used to learning a scientific approach. The scientific approach had the characteristics of highlighting the dimensions of observation, reasoning, discovery, validation, and explanation of a truth. If from an early age student were guided to skillfully observe, ask questions, reason, conduct experiments and conclude and communicate then indirectly the scientific character of students would be formed [1].

The worksheet compiled in this study was an integrated worksheet that had been integrated with $\mathrm{MBI}_{2}$. The use of integrated worksheets had an advantage over worksheets that only focus on student cognitive development. In addition, the worksheets made the learning became more well-structured because the worksheets were arranged according to learning activities [34]. This statement was also supported by the results of research which found that good worksheets were not only able to develop the cognitive aspects of students but also were able to develop students' potential in terms of attitudes and skills needed in responding to natural phenomena that occurred around them [35].

Based on the analysis of the Student Worksheet, students answered experimental questions by observing the phenomena that were displayed and giving further meaning to the observed phenomena. Examples of students' answers on the application of integrated worksheet in learning using $\mathrm{MBI}_{2}$ were presented in Figure 9. 


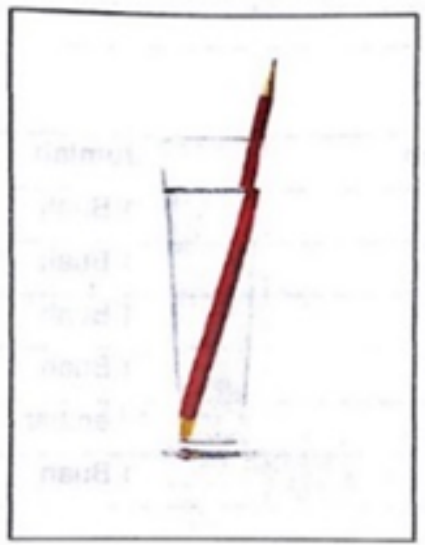

Dari fenomena tersebut apa yang dapat kamu ceritakan?

Dalam gambar tersebut, pada mulanga pensil lurus/tegak, Saat
sapensil dimasukkan dalam gelas berisi air, terlihat pensil
seolah-olah patah. Peristiwa tersebut disebabkan karena
sadarya

\section{Encrypted:}

\section{From that phenomenon, what can you tell?}

"In the picture, at first the pencil was upright, but when the pencil is put into a glass filled with water, it looks like the pencil is broken. The phenomenon was caused by the refraction of light."

Figure 9. Sample of Student's Answer in Worksheet about Refraction Phenomenon

Based on students' answers to the worksheet to answer the concept of refraction of light, students observed phenomena that raised and although he/she interpreted them using their own equivalent words, students could convey ideas or meanings that they took from these phenomena. Another example was the simulation that was raised in learning using $\mathrm{MBI}_{2}$ on the topic of refraction of light, showing illustrations of shaping the objects of refraction. Students observed the path of light that was deflected when passing through two mediums that had different densities. An example of an $\mathrm{MBI}_{2}$ display was presented in Figure 10.

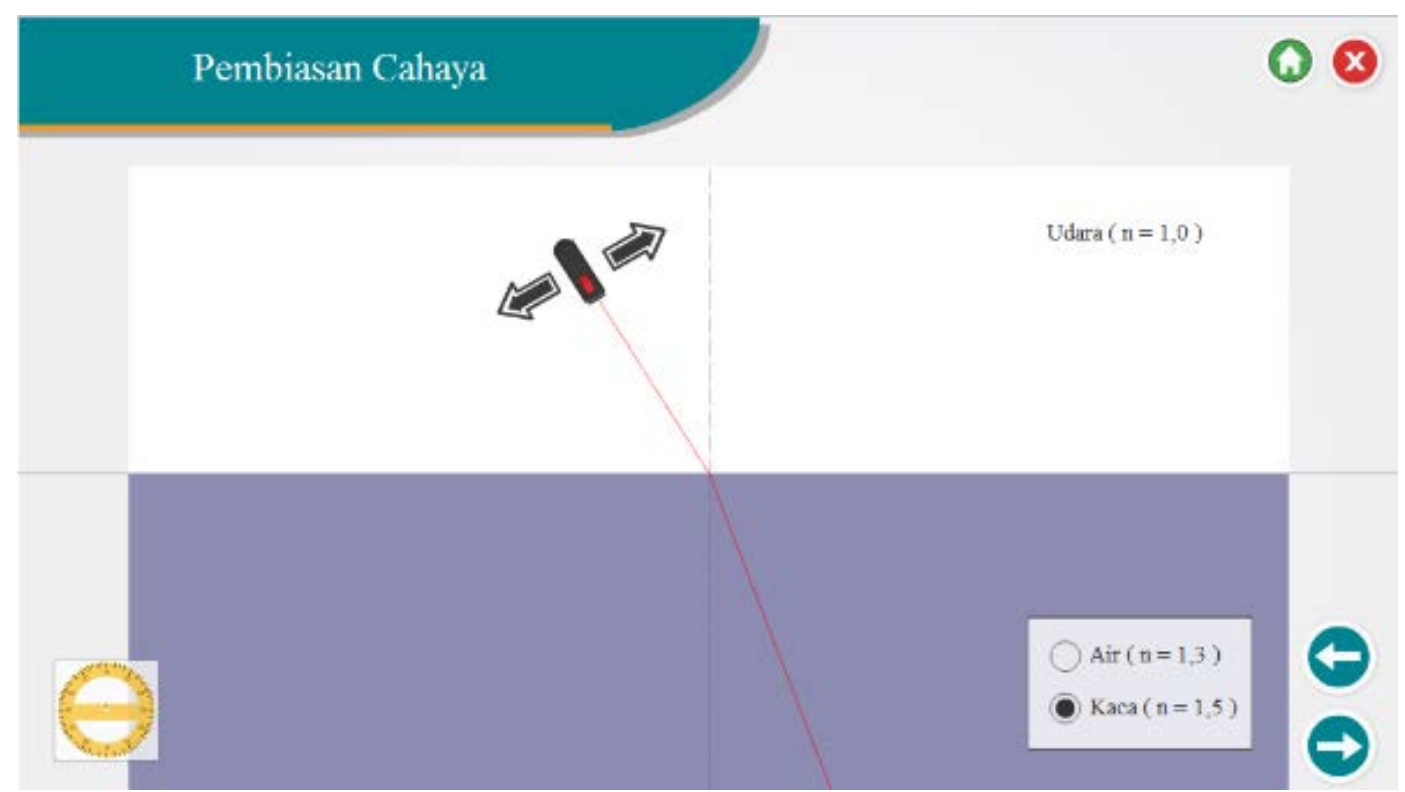

Figure 10. Example of Display in the Form MBI2 Simulation of Light Refraction through Two Different Media 


\section{H. Simpulan}

- Sinar datang dari medium renggang menuju medium yang lebih rapat akan dibiaskan mendekat1 garis normal.

- Sinar datang dari medium rapat menuju medium yang lebih renggang akan dibiaskan men jauh garis normal.

Encrypted:

H. Conclusion

light coming from the tenuous medium to a denser medium will be refracted close to the nomal line.

light coming from the dense medium to a more terwous medium will be refracted away from the normalline

Figure 11. Sample Student' Answers at Worksheet in Answering Phenomena Refraction in a Different Medium

From the simulation shown in Figure 10, students were trained to be able to provide an explanation of the law of refraction of light. This simulation example was a form of learning for students to practice basic skills to provide further explanation. Figure 11 showed an example of student's answer. Based on the picture above it was known that students answered the questions from the worksheet correctly. Students could deduce the outline of the law of refraction of light based on the meaning of the simulation displayed. With many forms of training for students to provide further explanation, students' critical thinking skills, especially in the aspect of providing further explanation, were increasingly developing. Analysis of student's answers was expected to be able to support the findings obtained from research.

The research data obtained to determine the profile of students' collaborative skills was gained from the collaborative skills observation sheet. To determine the profile of students' collaboration skills, the observer observed each individual in the group in learning activities using the light refraction material $\mathrm{MBI}_{2}$. There were four indicators collaboration skills assessed by an observer with a score of 1-4 in a range of integers. Data were obtained based on appraisals observer to the observation sheet used as students' collaboration skills profile in the form of a score with a scale of 4-16 as categorized by the categorization proposed by Arifin [26]. The results of data processing collaborated skills profiles were presented in Table 4.

Table 4. Collaborative Skill Profile

\begin{tabular}{|c|c|c|c|c|}
\hline $\begin{array}{c}\text { Total Score } \\
\text { of } \\
\text { Collaborative } \\
\text { Skills }\end{array}$ & $\begin{array}{c}\text { Maximum } \\
\text { Total } \\
\text { Score }\end{array}$ & $\begin{array}{c}\text { Average } \\
\text { Score }\end{array}$ & $\begin{array}{c}\text { Average } \\
\text { Maximum } \\
\text { Score }\end{array}$ & Category \\
\hline 425 & 528 & 12.88 & 16 & Good \\
\hline
\end{tabular}

For more detail, students' collaborative skills were measured by four indicators; cooperative skills and attitude of respect for members of the group, the skills to participate and contribute to the group, time management skills in the execution of the task, and the skills to be responsible on the results of joint work. To see a profile on each indicator collaboration skills, the data was presented in detail in Table 5. 
Table 5. Skills Profile Collaborate on Each Indicator

\begin{tabular}{|c|c|c|c|c|}
\hline No. & Indicators of Collaborative Skills & Total score & The average score & 3.30 \\
\hline 1 & $\begin{array}{c}\text { Cooperative skills and attitude of respect for } \\
\text { members of the group }\end{array}$ & 109 & 3.06 & Achieving competency \\
\hline 2 & $\begin{array}{c}\text { Skills to participate and contribute to the } \\
\text { group }\end{array}$ & 101 & 3.82 & Achieving competency \\
\hline 3 & $\begin{array}{c}\text { Time management skills in the execution of } \\
\text { tasks }\end{array}$ & 126 & 2.70 & Achieving competency \\
\hline 4 & $\begin{array}{c}\text { Skills to be responsible on the results of the } \\
\text { joint work }\end{array}$ & 89 & 12.88 & 425 \\
\hline
\end{tabular}

Collaboration skills score results were assessed by observers who were considered competent to assess the profile of students' collaborative skills. Long before learning began, the observer was initially given an explanation of the assessment of collaborative skills, following technical observations and an explanation of collaborative skills indicators and scoring criteria. This was done with the aim that the assessment of students' collaborative skills from each observer was valid so that the assessment for a student was the same from every observer. Observation activities were carried out at the second meeting, to measure collaborative skills after students got comprehensive treatment with learning using $\mathrm{MBI}_{2}$.

Based on the data processing, the average total score of students' collaborative skills was 12.88. Based on the guidelines for categorizing scores, the scores were considered into good category. Researcher's findings on the profile of students' collaborative skills obtained in this study were supported by previous research findings that in practicum activities, as a group all students could collaborate with each other and help each other in resolving problems given to the worksheet contained in $\mathrm{MBI}_{2}$ [12]. The research on students 'collaborative skills also found that the profile of students' collaborative skills was in the good category.

The use of integrated worksheet and learning based on a scientific approach in groups for learning using $\mathrm{MBI}_{2}$ could also enable students to practice collaborative skills. This is in line with Niemi who stated that practicing collaborative skills with students could improve learning outcomes by providing opportunities for students to acquire and share knowledge with their colleagues [23]. Other research findings concluded that a scientific approach could improve students' collaborative skills [36].

Based on Table 5, the average score of students' collaborative skills was a score of 3 and above on the indicators of cooperation skills and attitudes of respecting group members, skills in participating and contributing to groups, and time management skills in working on tasks. From the interpretation of the scores of the three indicators, it can be stated that the average student has achieved the competence expected for the indicators of cooperative skills and attitudes of respecting group members, the skills of participating and contributing to the group, and the time management skills in working on tasks. For the average student score on the fourth indicator, namely the skills responsible for joint work, has a score of 2.70 with a score interpretation almost reaching competence. This indicator is an indicator with the average score of the smallest students compared to other indicators.

Before practicum activities were carried out, the teacher guides students to determine the practicum groups. The determination of student groups was arranged freely, so students could determine their colleagues to collaborate. This group learning allowed students to practice collaborating with their friends. Students were trained to collaborate with $\mathrm{MBI}_{2}$ assisted as a means to solve the problems given by each of them together with peers when it was viewed from the implementation of learning, there were some students who were less active in responding to teacher questions and in conducting experiments individually [12].

Based on the results of research that has been done, it is implied that the use of $\mathrm{MBI}_{2}$ can be an alternative teacher solution to improve critical thinking skills and find out the profile of students' collaborative skills. These skills are two of the $21^{\text {st }}$ century skills that are expected to be developed by students. However, research that has been done is far from perfection because there are some shortcomings and requires improvements to get better results in the future.

\section{Conclusions}

The $21^{\text {st }}$ century skills are skills required by the world community in facing the $21^{\text {st }}$ century. Creativity is needed in adjusting to work that began to be flexible in the $21^{\text {st }}$ century and collaboration is needed to improve the ability to work together. Moreover, $21^{\text {st }}$ century is familiar with technology thus many educators struggle to keep up with the changing technological context. Multimedia Based Integrated Instruction $\left(\mathrm{MBI}_{2}\right)$ learning media is one solution to answer the problems. $\mathrm{MBI}_{2}$ is integrated multimedia which contains learning multimedia, learning 
tools, teaching materials (e-books) and assessment.

Based on research that has been done, the following results from present investigations seem worthy of emphasis:

1. The use of $\mathrm{MBI}_{2}$ in science learning can improve students' critical thinking skills on the material of light refraction, indicated by the acquisition of an $\mathrm{N}$-gain value of 0.42 which was considered as the medium category. The highest aspects of critical thinking skills of students were found in aspect making further explanation.

2. The profile of students' collaborative skills on light refraction material was shown with an average score of 12.88 which was included in the good category. The highest average score of collaborative skills is in indicator time management skills in the execution of tasks.

\section{REFERENCES}

[1] Ministry of Education and Culture Republic of Indonesia. Online available from http://litbang.kemdikbud.go.id/index.php/index-berita-kurik ulum/243-kurikulum-2013-pergeseran-paradigma-belajar-a bad-21.

[2] M. Hosnan, Scientific and Contextual Approach in $21^{\text {st }}$ Century Learning, Ghalia Indonesia, Bogor, 2014.

[3] O. Kurniaman, E. Noviana, "Implementation of Curriculum 2013 in Improving Skills, Attitudes and Knowledge", Jurnal Primary Program Studi Pendidikan Guru Sekolah Dasar Fakultas Keguruan dan Ilmu Pendidikan Universitas Riau, Vol.6, No.2, 389-396, 2014.

[4] M. C. Sahin, "Instructional Design principles for 21st Century Learning Skills,” Procedia Social and Behavioral Sciences, vol. 1, pp. 1464-1468, 2009.

[5] Partnership for 21st Century Skills, P21 Framework Definitions. The Partnership for 21st Century Learning, 2015.

[6] B. Trilling and C. Fadel, 21st century skills: Learning for life in our times, Jossey-Bass, San Francisco, CA, US, 2009.

[7] P. Saxena, "JOHARI WINDOW: An Effective Model for Improving Interpersonal Communication and Managerial Effectiveness,” SIT Journal of Management, vol. 5, no. 2, pp. 134-146, 2015.

[8] J. Lambert and P. Cuper, "Multimedia technologies and familiar spaces: 21st-century teaching for 21st-century learners," Contemporary Issues in Technology and Teacher Education, vol. 8, no. 3, pp. 264- 276, 2008.

[9] F. Fathan, Liliasari, I. Rohman, "Learning Chemical Equilibrium with Interactive Multimedia to Enhance the Mastery of Concepts and Critical Thinking Skills of High School Students”, Jurnal Riset dan Praktik Pendidikan Kimia, Vol. 1, No. 2, 76-83, 2013.
[10] R. Wondal, "Effects of Computer Assisted Instruction Learning Media on Student Learning Outcomes”, Jurnal Edukasi, Vol. 3, No. 2, 360-366, 2015.

[11] P. Siahaan, A. Suryani, I. Kaniawati, E, Suhendi and A. Samsudin, “Improving Student's Science Process Skill through Simple Computer Simulation on Linear Motion Conceptions,” Journal of Physics: Conference Series, vol. 812, 2017.

[12] H. Hermawan, P. Siahaan, E. Suhendi E and A. Samsudin, "Promoting collaboration skills on reflection concept through multimedia-based integrated instruction," AIP Conference Proceedings, vol. 1848, 2017.

[13] S. S. Bhakti, A. Samsudin, D. T. Chandra and P. Siahaan, "Developing multiple-choices test items as tools for measuring the scientific-generic skills on solar system," AIP Conference Proceedings, vol. 1848, 2017.

[14] A. Samsudin et al., “Seventh Grade Students' Scientific Creativity Test: A Preliminary-Study on Earth Science Context,” IOP Conf. Ser.: Mater. Sci. Eng., vol. 288 012012, 2018

[15] S. R. Hidayat, A. H. Setyadin, I. Kaniawati, E. Suhendi, P. Siahaan, H. Hermawan, A. Samsudin, "Development of Problem Solving Skills Test Instruments on Vibrations, Waves, and Sounds Material, JPPPF - Jurnal Penelitian \& Pengembangan Pendidikan Fisika, Vol. 3, 157-166, 2017.

[16] D. Yulianawati, M. Muslim, L. Hasanah and A. Samsudin, "A case study of analyzing 11th graders' problem solving ability on heat and temperature topic," Journal of Physics: Conference Series, vol. 1013 012042, 2018.

[17] F. Nurasiah, R. Risma, P. Siahaan, A. Samsudin, E. Suhendi, "Increasing Critical Thinking Ability of Junior High School Students Through Multimedia-Based Learning on Optical Materials”, Proceeding of SINAFI, 2015.

[18] P. Siahaan, A. Suryani, I. Kaniawati, E. Suhendi and A. Samsudin, "Improving Students' Science Process Skills through Simple Computer Simulations on Linear Motion Conceptions," Journal of Physics Conference Series, vol. $8121012017,2017$.

[19] J. Wang and G. A. Morgan, "Pre-experimental designs," Encyclopedia of research design, vol. 2, 1081-1086, 2010.

[20] N. J. Salkind, Encyclopedia of research design, SAGE Publications, California, 2010.

[21] M. Tawil, Liliasari, "Complex Thinking and Implementation in Science Learning", Badan Penerbit UNM, Makassar, 2013.

[22] R. H. Ennis, The Nature of Critical Thinking: An Outline of Critical Thinking Dispositions and Abilities, Online available http://faculty.education.illinois.edu/rhennis/documents/The NatureofCriticalThinking_51711_000.pdf.

[23] H. Niemi, V. Harju, M. Vivitsou, K. Viitanen, J. Multisilta and A. Kukkokanen, "Digital Storytelling for 21st Century Skills in Virtual Learning Environments," Scientific Research, pp. 657-671, 2014.

[24] E. R. Lai, Collaboration: A Literature Review, Online avalilable http://www.pearsonassessments.com/research. 
[25] Partnership for 21st Century Skills, A Report and Mile Guide for 21st Century Skills Retrieved September 10, 2008, Online available http://www.21stcenturyskills.org/do wnloads/P21_Report.pd.

[26] International Reading Association/NCTE 2012 Read Write Think “Collaborative Work Skills Rubric”.

[27] R. R. Hake, Analyzing Change/Gain Scores, Indiana University, Indiana, 1999.

[28] Z. Arifin, Evaluasi Pembelajaran, PT. Remaja Rosdakarya, Bandung, 2014.

[29] S. Husein, L. Herayanti and Gunawan, "Effect of Using Interactive Multimedia on the Mastery Concepts and Critical Thinking Skills of Students on Temperature and Heat Materials,” Jurnal Pendidikan Fisika dan Teknologi, vol. 1, issue 3, pp. 221-225, 2015.

[30] N. E. Purnamasari, I. Kaniawati, E. Suhendi and P. Siahaan, "Enhancing Critical Thinking Ability in Learning Heat Transfer Through Computer Multimedia," Proceeding of Seminar Nasional Fisika (SiNaFi), 2015.

[31] A. Samsudin and W. Liliawati, "The Effectiveness of Physics Learning Using Computer Animation Media to Enhance Critical Thinking Skills of High School Students,” Proceeding of Seminar Nasional Penelitian, Pendidikan dan Penerapan MIPA, 2011.

[32] S. R. Hidayat, The Use of MBI2 in Science Learning to Improve Critical Thinking Skills and Problem Solving Middle School Students on Vibrations, Waves, and Sounds Material. Thesis of Bachelor Degree, Universitas Pendidikan Indonesia, Bandung, 2017.

[33] R. Mahmuzah, “Increasing Mathematical Critical Thinking Ability of Middle School Students Through Problem Posing Approach,” Jurnal Peluang, vol. 4, no. 1, pp. 2302-5158, 2015.

[34] Trianto, Designing innovative-progressive learning models, Kencana, Jakarta, 2011.

[35] E. S. Winahyu, H. Kartini and L. Bintartik, "Development of Scientific-Based Student Worksheet to Grow Scientific Character in Elementary Students," Kajian Teori dan Praktik Pendidikan, vol. 25, pp. 73-81, 2016.

[36] A. P. Daud and Dewanto, "Implementation of Scientific Approach in Improving Collaborative Ability and Student Learning Outcomes at SMK Negeri 5 Surabaya," Implementasi Pendekatan Ilmiah (Science Approach), pp. 123-129, 2016. 